\title{
Determination of Moisture, Ash, Protein, Polyphenolic, Flavonoids, and Amino Acid Contents and Antioxidant Capacity of Dried Mekai (Pycnarrhena tumefacta Miers) Leaf as Potential Herbal Flavor Enhancers
}

\author{
Miftakhur Rohmah $^{1}$, Bernatal Saragih ${ }^{1}$, Nur Amaliah $^{1}$, Kristopal Kristopal $^{1}$, Yuda \\ Hendriansyah Eka Putra ${ }^{1}$, Anton Rahmadi ${ }^{1,2 *}$ \\ ${ }^{1}$ Dept of Agricultural Products Technology, Faculty of Agriculture, Mulawarman University, Samarinda, East \\ Kalimantan, 75119, Indonesia \\ ${ }^{2}$ Research Center for Medicine and Cosmetics from Tropical Rain Forests (PUI-PT Oktal), Mulawarman University, \\ Samarinda, East Kalimantan, 75119, Indonesia \\ *Corresponding author. Email: arahmadi@gmail.com
}

\begin{abstract}
Mekai leaf (Pycnarrhena tumefacta Miers) is used by the Dayaks tribe as a glutamic acid substitute to enhance the umami flavor of traditional foods. A dried mekai leaf is applied directly to the pan during cooking. Mekai contains glutamate, but its amino acids and other properties such as antioxidant capacity and phenolic-related substances have not been quantified. This study aims to determine the moisture, ash, protein, polyphenolic, flavonoids, amino acid content, and the antioxidant capacity of Mekai, leaves were dried in the sun, gas, and electric ovens at various temperatures and times. The moisture content of dried Mekai leaves was 6.95-9.30\% (w/w). The ash and protein contents of dried Mekai leaves were 4.22-5.47 \% and 15.7-20.6 \% (w/w), respectively. The optimal moisture and ash content conditions were obtained after 3.5 hours of electric oven drying at $60{ }^{\circ} \mathrm{C}$. Different drying methods had no discernible effect on protein content; excepted for electric oven drying at $60{ }^{\circ} \mathrm{C}$ for 3.5 hours, which results in protein content of 16.90.0 percent (w/w). Sundried Mekai had the lowest TPC value, whereas samples dried in an electric oven had a higher TPC value than samples dried in a gas oven. Both electric and gas oven drying at $60{ }^{\circ} \mathrm{C}$ for 2.5 hours resulted in significantly higher levels of flavonoids and antioxidant activity than other drying conditions in the same group. Mekai leaves were identified by the presence of arginine, glutamate, aspartic acids, and leucine. After sun drying, arginine, leucine, and isoleucine concentrations increased more than other amino acids.
\end{abstract}

Keywords: Amino acid, Flavonoids, Flavor enhancers, Polyphenolic, Pycnarrhena tumefacta

\section{INTRODUCTION}

Mekai leaf (Pycnarrhena tumefacta Miers) is local wisdom for the Dayaks tribe as a substitute for glutamic acid to increase the umami taste for traditional foods. However, the P. tumefacta plant is often identified as Albertisia papuana [1], while both plant species may be incompatible. Taxonomically, Mekai is more suited to $P$. tumefacta [2]. However, this confusion is not the scope of the current report. Usually, Mekai leaves being dried and applied directly during cooking [3, 4]. This unique culinary substance is rarely characterized by moisture, ash, protein, polyphenolic, and flavonoid contents. Also, the antioxidant capacity and amino acid contents of Mekai leaf are yet to be reported [2] (Saupi et al., 2020).

Typically, animal-derived material and yeast obtain substances to increase umami taste $[5,6]$. These unique properties of Mekai may open the application of derived extract to a niche market, i.e., the vegan community that has a stringent diet specification. Glutamate is a principal active substance to umami taste among the amino acids affecting the taste [7]. Recently, arginine was employed to modify food taste related to 6-n-Propylthiouracil (PROP) tasting that positively affects mood and eating behaviors [8]. Further, arginine reduces taste fatigue in several supplements [9]). 
Regarding the preparation of dried Mekai, gas and electric drying can be utilized as the technologies are readily available in the market. Furthermore, the drying method may play a role in the active substance and amino acid contents of Mekai leaf, as indicated from research with other leaves $[10,11]$. Therefore, this research aims to characterize moisture, ash, protein, polyphenolic, flavonoids, amino acid contents, and the antioxidant capacity of Mekai leaves dried with sun exposure, gas, and electric oven at various temperatures and times.

\section{METHOD}

\subsection{Materials and Tools}

The raw materials for mature and dark green Mekai leaves were obtained from local farmers in Barong Tongkok, West Kutai Regency. Chemicals used were Folin-Ciocaltea reagent (Merck, USA), ethanol absolute (Fulltime, China), $\mathrm{Na}_{2} \mathrm{CO}_{3}$ (Sigma-Aldrich, USA), 2,2diphenyl-1-picrylhydrazyl (DPPH) (Sigma-Aldrich, USA), aqua dest (Faperta-Unmul, Indonesia), methanol (Fulltime, USA), $\mathrm{NaOH}$ (Merck, USA), tannic acid standard (Sigma-Aldrich, USA), gallic acid standard (Sigma-Aldrich, USA), $\mathrm{NaNO}_{2}$ (Sigma-Aldrich, USA), $\mathrm{AlCl}_{3}$ (Sigma-Aldrich, USA), and quercetin standard (Sigma-Aldrich, USA). The tools used in this research are analytical balance (ACIS, China), blender (Miyako), ultra sonicator (Delta D68H, China), hot plate (Faithful, type SH-24, China), centrifuge (Dragon-type LC-045, China), Spectrophotometer UV-VIS (Eppendorf, Germany), and Vortex (Faithful, China).

\subsection{Material Preparation}

Mekai leaves are sorted first by removing damaged leaves. Then, Mekai leaves are ready to be dried using

Tabel 1. Drying Parameters for Mekai leaves three dryers, namely gas oven dryer, electric oven dryer, and dryer housing (control). First, drying was conducted in an oven (gas and electric) at a temperature of $50^{\circ} \mathrm{C}$ and $60^{\circ} \mathrm{C}$. The drying time was 1.5 hours, 2.5 hours, and 3.5 hours (Table 1). Next, Sun-drying was conducted in a drying house for three days with temperatures ranging from $27-35{ }^{\circ} \mathrm{C}$. Finally, the dried Mekai leaves are mashed using a blender and then sieved with an 80-mesh sieve.

\subsection{Analysis Method}

The analysis included water content, ash, protein [12], phenol analysis using the Folin-Ciocalteu method $[13,14]$. In addition, flavonoids were measured by spectrophotometric method [15], antioxidant analysis using the DPPH method [16], amino acid analysis using the HPLC method [17].

\subsubsection{Moisture, Ash, and Protein Contents Analysis}

Moisture, ash, and protein contents were analyzed with AOAC standardized method (AOAC, 2020).

\subsubsection{Phenolic Content Analysis}

Total phenolic analysis was performed spectrophotometrically using the Folin-Ciocalteu method (Mu'Nisa et al., 2012; Nurhayati et al., 2012), and gallic acid was used as a comparison (Sigma-Aldrich, USA) First, the total phenolic content in the extract was expressed in gallic acid equivalent (GAE). Next, the sample was weighed as much as $5 \mathrm{mg}$ dissolved in a tube in $2 \mathrm{~mL}$ of $95 \%$ ethanol. Next, $5 \mathrm{~mL}$ of distilled water and $0.5 \mathrm{~mL}$ of Folin-Ciocalteau reagent (Sigma-Aldrich, USA) $50 \%(\mathrm{v} / \mathrm{v})$ were added. The sample was left for 5 minutes, and $5 \%(\mathrm{w} / \mathrm{v}) \mathrm{Na}_{2} \mathrm{CO}_{3}$ (Sigma-Aldrich, USA)

\begin{tabular}{|l|c|c|c|}
\hline \multirow{2}{*}{ Code } & \multicolumn{3}{|c|}{ Drying Parameters } \\
\cline { 2 - 4 } & Oven type & Drying temp. $\left({ }^{\circ} \mathrm{C}\right)$ & Duration (hours) \\
\hline G11 & Gas & 50 & 2.5 \\
\hline G12 & Gas & 50 & 3.5 \\
\hline G20 & Gas & 60 & 1.5 \\
\hline G21 & Gas & 60 & 2.5 \\
\hline G22 & Gas & 60 & 3.5 \\
\hline SD & Sun Drying & $35-50^{\circ} \mathrm{C}$ & Approx. 6 hours \\
\hline E11 & Electric & 50 & 2.5 \\
\hline E12 & Electric & 50 & 3.5 \\
\hline E20 & Electric & 60 & 2.5 \\
\hline E21 & Electric & 60 & 3.5 \\
\hline E22 & Electric & 60 & \\
\hline
\end{tabular}


solution was added until the total volume reached $10 \mathrm{~mL}$. Then the solution was homogenized in the dark for 1 hour. After being homogeneous, the absorbance of the solution was measured at a wavelength of $752 \mathrm{~nm}$.

\subsubsection{Flavonoids Content Analysis}

Total Flavonoids were carried out by weighing $1 \mathrm{mg}$ of extract and then dissolving up to $10 \mathrm{~mL}$ with $95 \%$ ethanol (Kimia Farma, Indonesia). The extract that had been dissolved in ethanol was added with $0.7 \mathrm{~mL}$ of distilled water. Then $0.1 \mathrm{~mL}$ of $5 \%$ NaNO2 (Sigma Aldrich, USA) was added to the mixture. After 5 minutes, $0.1 \mathrm{~mL}$ of $10 \% \mathrm{AlCl} 3$ was added (Sigma Aldrich, USA). After 6 minutes, $0.5 \mathrm{~mL}$ of $1 \mathrm{M} \mathrm{NaOH}$ (Merck, USA). All ingredients were mixed evenly and then incubated for 10 minutes. The absorbance was measured at a wavelength of $510 \mathrm{~nm}$ with a blank of $1 \mathrm{~mL}$ of sample replaced with $1 \mathrm{~mL}$ of $95 \%$ ethanol solvent. The results obtained were plotted against a standard catechin curve (Sigma Aldrich, USA) prepared in the same way. Total flavonoids are expressed as mg equivalent of catechins per g dry weight.

\subsubsection{Antioxidant Activity Analysis}

Total antioxidant was carried out using a spectrophotometric method with DPPH (2,2-diphenyl-1picrylhydrazyl) (Farhan et al., 2012). A total of $1 \mathrm{ml}$ of the extract diluted in ethanol (Kimia Farma, Indonesia) was added to $1 \mathrm{~mL}$ of DPPH $(0.15 \mathrm{mM}$ in ethanol) (Sigma Aldrich, USA). At the same time, a control consisting of $1 \mathrm{~mL}$ DPPH with $1 \mathrm{~mL}$ ethanol was prepared. The reaction mixture was mixed well by hand and incubated at room temperature for 30 minutes in the dark. The absorbance was measured at $519 \pm 2 \mathrm{~nm}$. Vitamin C (Sigma Aldrich, USA) was used as a positive control, and ethanol was used as a blank. The DPPH ability of the extract was calculated using the following equation:

Total antioxidants $(\%)=\frac{(\text { control absorbance-sample absorbance) }}{\text { control absorbance }} \times 100 \%$

The control absorbance is the absorbance of DPPH + ethanol

The absorbance of the sample is the absorbance of the DPPH radical + sample.

The parameter to interpret the results of the DPPH test is the IC50 value. (Inhibitory Concentration). IC50 is the concentration of substrate or sample solution that can reduce DPPH activity by $50 \%$. The smaller the IC50 value, the higher the antioxidant activity. The IC50 value was obtained from the linear equation of the percent inhibition of DPPH radicals on several concentrations of sample extracts. The linear regression equation is $\mathrm{y}=\mathrm{ax}$ $+\mathrm{b}$

\subsubsection{Amino acid analysis}

The amino acid analysis (AAA) used orthophthalaldehyde (OPA) fluorescence standardized method from Unit Laboratorium Jasa Pengujian, Kalibrasi dan Sertifikasi Institut Pertanian Bogor procedure number IK.LP-04.7-LT-1.0 [17].

The conditions for HPLC (Shimadzu) were column ThermoScientific ODS-2Hypersil, buffer A and B gradient mobile phase flow rate at $1 \mathrm{~mL} /$ minute, detector Fluorescence (Shimadzu). Buffer A consisted of Na-acetate ( $\mathrm{pH} 6,5 ; 0,02$ $\%)$, Na-EDTA $(0,005 \%)$, methanol $(9,00 \%)$, tetrahydrofuran (THF) $(1.50 \%)$ dissolved in 1 liter of ultrapure water (Merck-Millipore). This buffer was filtered with $0.45 \mu \mathrm{m}$ Millipore paper and was used within five days at room temperature $\left(28 \pm 2^{\circ} \mathrm{C}\right)$, stored in dark bottles, and filled with $\mathrm{He}$ or Nitrogen gas. Buffer B: consists of $95 \%$ methanol and ultrapure water (Merck-Millipore). Filter with 0.45-micron Millipore paper.

\section{RESULTS AND DISCUSSION}

\subsection{Moisture Content}

Moisture content is the leading indicator of the adequacy of the drying process of a functional food raw material. Moisture content due to drying by different methods generally ranges between 4.5 and $10 \%(\mathrm{w} / \mathrm{w})$ $[18,19]$. In this study, the moisture content values obtained from the three drying methods were between $6.95 \pm 0.09$ and $9.30 \pm 0.60 \%$ (w/w). When compared with drying using sunlight, different moisture content values were obtained from samples dried in a gas oven at $50{ }^{\circ} \mathrm{C}$ for 2.5 hours (G11), electric oven at $50{ }^{\circ} \mathrm{C}$ for 3.5 hours (E12), electric gas oven $60{ }^{\circ} \mathrm{C}$ for 2.5 hours (E21), and an electric oven at $60{ }^{\circ} \mathrm{C}$ for 3.5 hours (E22). The lowest moisture content value was obtained from drying Mekai leaves using an electric oven at $60{ }^{\circ} \mathrm{C}$ for 3.5 hours. In general, in addition to the electric gas oven treatment at $60{ }^{\circ} \mathrm{C}$ for 2.5 hours (E21), the use of gas and electric ovens provided a lower moisture content value when compared to drying in the sun. Based on previous studies, sun drying is still widely practiced despite the high variability of moisture content in sun-drying [20]. However, mechanical dryers provide a more beneficial drying effect in terms of moisture content and better functional properties when compared to drying using sunlight [21, 22, 23]. 


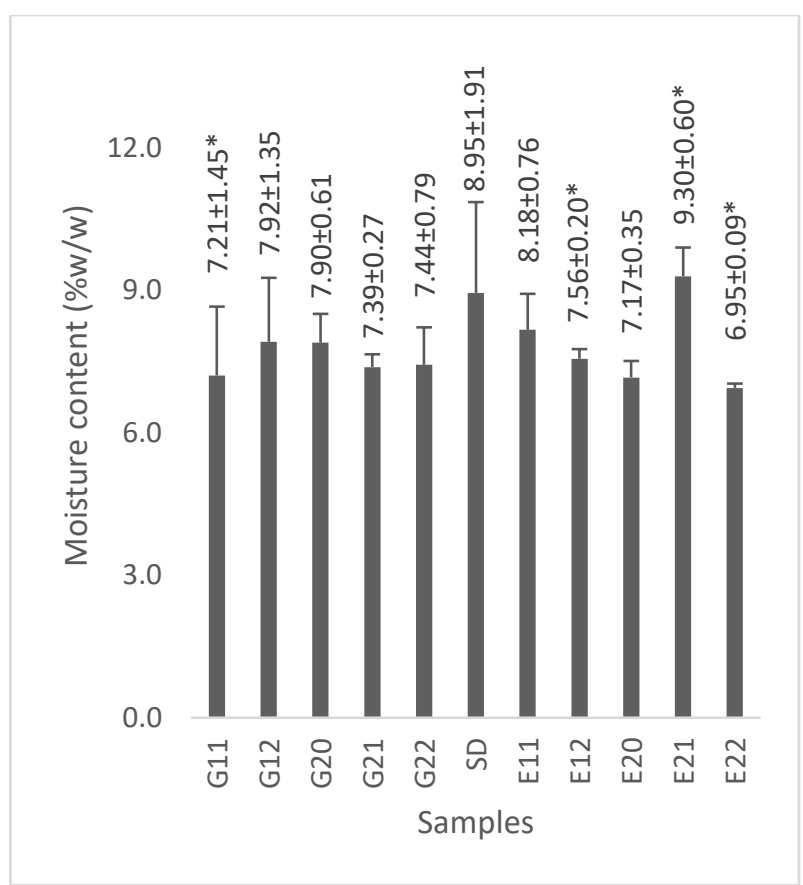

Figure 1. The moisture content of dried Mekai leaves from sun drying, gas, and electric ovens at various drying temperatures and durations.

Values are presented in average \pm standard deviation. Asterisk (*) indicated the respective value significantly different $(\mathrm{p}<0.05)$ in comparison to the sun-dried value.

\subsection{Ash Content}

Commonly, the ash content of a dried product will not be varied regardless of the drying method. Ash is a crude indicator for minerals, and its content will not be affected by drying [24]. However, slight variations of ash content may indicate the uneven spread of minerals in the samples [25]. These conditions are shown in Figure 2, except for samples dried with an electric oven at $60{ }^{\circ} \mathrm{C}$ for 3.5 hours (E22). The ash contents of dried Mekai leaves are not significantly different concerning the various drying methods tested. Several plants have phytoextraction properties that absorb minerals from surrounding and store them in plant parts. Therefore, Mekai may be regarded as a fair source of minerals, and the mineral content is relatively in the same amount as that in shoots [26]. In summary, drying methods did not affect ash content, except in some pre-drying treatment conditions. For example, applying acidic blanching before drying may leach out minerals from dried material [27].

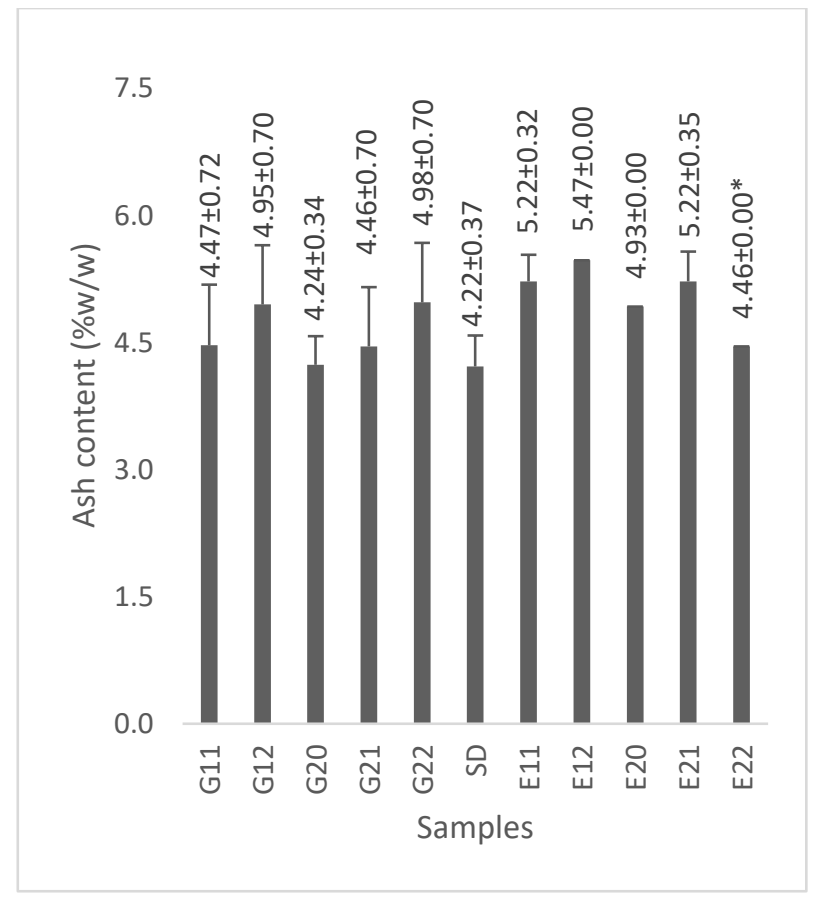

Figure 2. Ash content of dried Mekai leaves from sun drying, gas, and electric ovens at various drying temperatures and durations.

Values are presented in average \pm standard deviation. Asterisk (*) indicates the respective value significantly different $(\mathrm{p}<0.05)$ in comparison to the sun-dried value.

\subsection{Protein Content}

Protein content may be affected by drying due to heatprone properties, enzymatic degradation, and microbial metabolism that occurred during the drying process [28]. From all mechanical drying treatments compared to sun drying, the protein contents of Mekai leaves were not significantly different, except for samples dried with an electric oven at $60{ }^{\circ} \mathrm{C}$ for 3.5 hours (E22) (Figure 3). However, the Kjeldahl method is used as it only is based on the $\mathrm{N}$-content. Therefore, the composition and quality of amino acids and peptides could not be observed with the Kjeldahl method [29, 30]. Further, the conversion factor is another issue. Therefore, finding the most suitable conversion factor representing Mekai leave is essential to measure the protein content [31]. We use 4.4 as a conversion factor in this regard, as referenced from previous research $[32,33]$. Protein content preservation is vital for maintaining the flavor of food material [34]. Oven drying may improve the conservation of protein content, as observed in Holothuria tubulosa dried product [35]. 


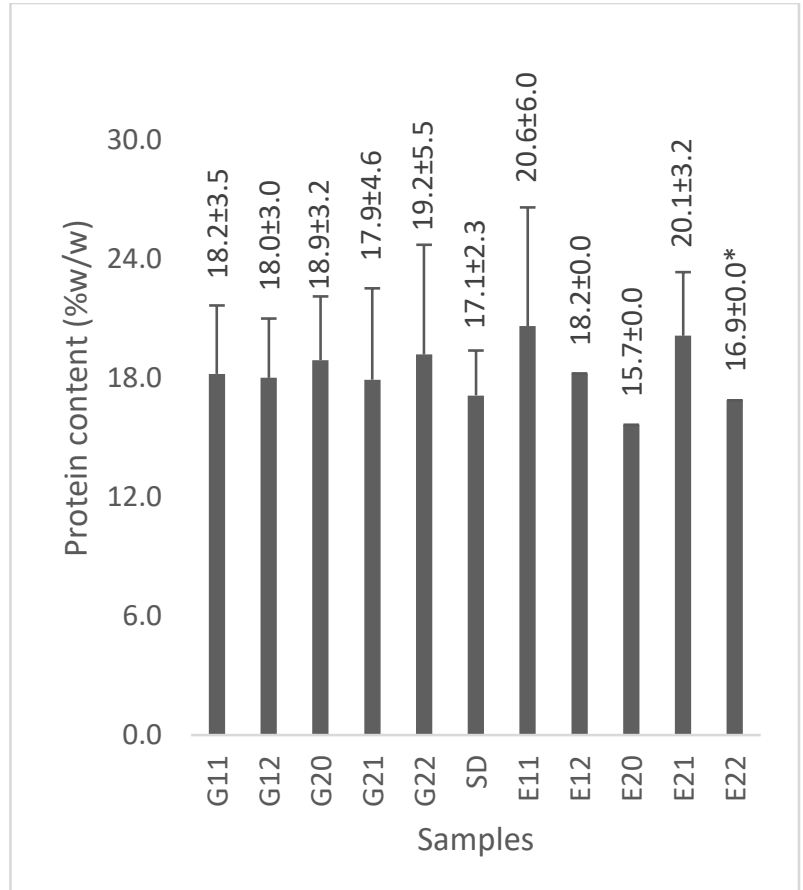

Figure 3. The protein content of dried Mekai leaves from sun drying, gas, and electric ovens at various drying temperatures and durations.

Values are presented in average \pm standard deviation. Asterisk $(*)$ indicates the respective value significantly different $(\mathrm{p}<0.05)$ in comparison to the sun-dried value.

\subsection{Phenolic Substance}

The drying method affects total phenolic contents (TPC) preservation in dried Gynura pseudochina leaf [36]. Gas and electric ovens are used as alternatives to sun drying in this study. Sundried Mekai has the most negligible value of TPC, while samples dried with an electric oven are in the group of better TPC than samples dried with a gas oven (Figure 4). An electric oven may have less fluctuation of temperature. In recent research, freeze and microwave drying indicate potential improvement as a better drying method in preserving TPC [37]. Different drying methods preserve active substances and responsibly use energy, finding the most sustainable drying method for a specified raw material [38]. In this regard, TPC may act as a marker to an active substance that is valuable to be preserved during the drying stage.

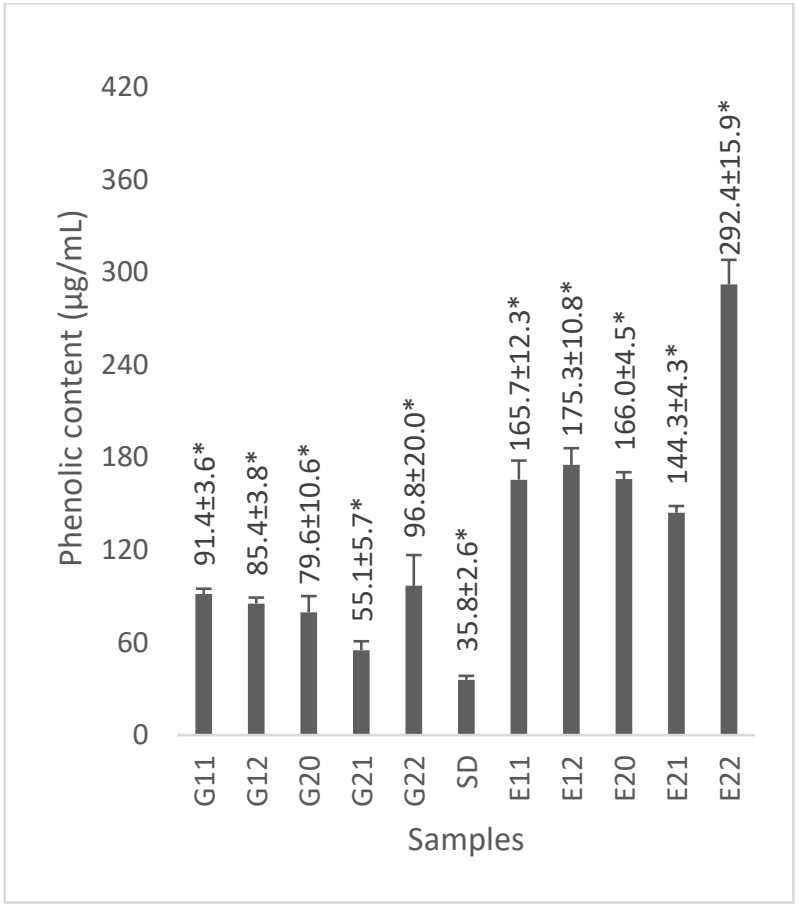

Figure 4. Phenolic content of dried Mekai leaves from sun drying, gas, and electric ovens at various drying temperatures and durations.

Values are presented in average \pm standard deviation. Asterisk (*) indicates the respective value significantly different $(\mathrm{p}<0.05)$ in comparison to the sun-dried value.

\subsection{Flavonoids}

Previous research observed that drying methods might significantly modify Moringa oleifera leaf's phytoconstituents, including phenolics and flavonoids. The study summarized preferable drying methods for Moringa oleifera leaf in consecutive manners, starting from freeze-drying, air drying, sun drying, and the latter, oven drying [39]. The flavonoid contents of Mekai leaves are varied with the combination of drying methods and conditions (Figure 5). The highest flavonoid content from electric oven drying was at $60^{\circ} \mathrm{C}$ for 2.5 hours (E21). Gas oven drying showed a potential usage when it was set at $60{ }^{\circ} \mathrm{C}$ for 2.5 hours (G21). However, the sun drying may not preserve phenolic content in comparison to several combinations, i.e., electric oven drying at $50{ }^{\circ} \mathrm{C}$ for 3.5 hours (E12), electric oven drying at $60{ }^{\circ} \mathrm{C}$ for 2.5 hours (E21), electric oven drying at $60{ }^{\circ} \mathrm{C}$ for 3.5 hours (E22), gas oven drying at $60{ }^{\circ} \mathrm{C}$ for 2.5 hours (G21), and gas oven drying at $50{ }^{\circ} \mathrm{C}$ for 2.5 hours (G11). Thus, the method of drying may produce different results for different products. Direct sun exposure maintained higher flavonoid content than under the shade and oven methods in drying three vegetables, namely Corchorus olitorius, Amaranthus cruentus, and Beta vulgaris [40]. Oven drying emerged as a preferable method for coffee fruit, giving higher phenolic and flavonoid contents than 
shade drying at room temperature [41]. However, oven drying showed a detrimental effect on retaining phenolic and flavonoids content when drying at higher temperature $\left(>100^{\circ} \mathrm{C}\right)$. Therefore, it is better to limit the oven drying temperature to not more than $100{ }^{\circ} \mathrm{C}$ as observed in a tea product [11].

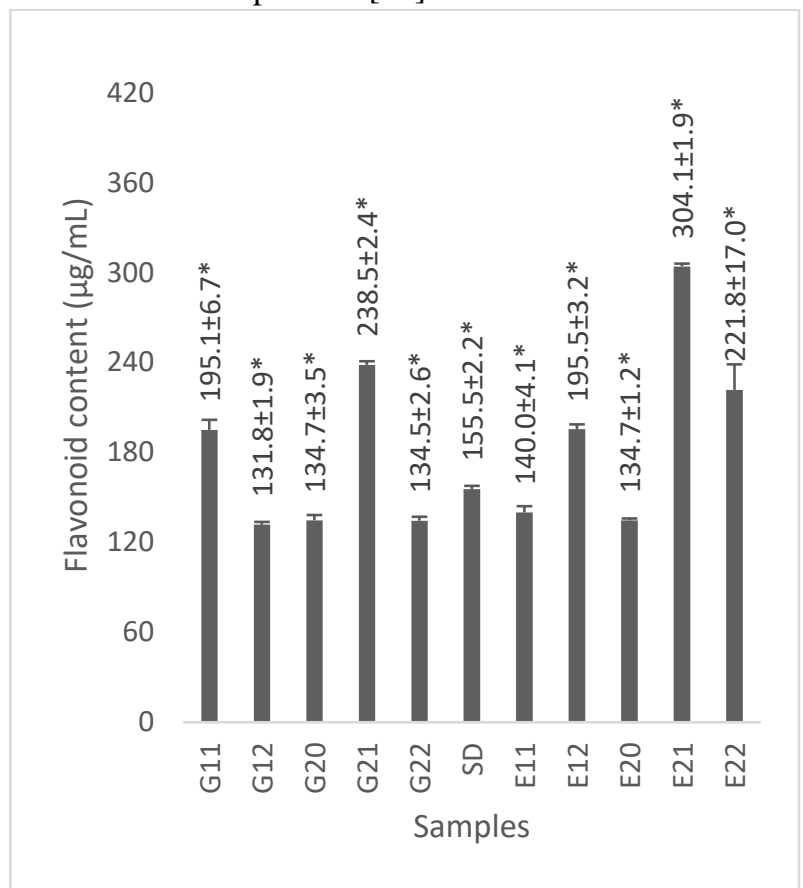

Figure 5. Flavonoid content of dried Mekai leaves from sun drying, gas, and electric ovens at various drying temperatures and durations.

Values are presented in average \pm standard deviation. Asterisk (*) indicates the respective value significantly different $(\mathrm{p}<0.05)$ in comparison to the sun-dried value.

\subsection{Antioxidant Activity}

Antioxidant activity quantification can be deduced from the half-maximal inhibitory capacity when challenged by DPPH radicals. The $\mathrm{IC}_{50}$ value is inversely proportional to the sample's scavenging free radicals $[42,43]$. Regardless of the variability and its consistency, sun drying is still the most popular method cost-wise. Some applications may help reduce antioxidant capacity declines compared to mechanical drying [44]. Mekai leaves dried under sun exposure produced the fourth-best antioxidant activity. Combinations of drying temperature and time have created a significant difference in the antioxidant activity, with electric oven drying at $60^{\circ} \mathrm{C}$ for 2.5 hours (E21), followed by electric oven drying at $50^{\circ} \mathrm{C}$ for 2.5 hours (E11). The best combination was obtained at $60{ }^{\circ} \mathrm{C}$ for 2.5 hours (Figure 6 ). The method of drying determines the antioxidant activity. For example, sun drying has the worst effect on retaining antioxidant activity in grape products than other drying methods [45]. Compared to other drying methods, oven drying positively affects the radical scavenging activity for Camellia sinensis [11]. Further, the use of vacuum drying may better protect the oxygenation of oil-based antioxidants as presented in Thymus daenensis essential oil [46].

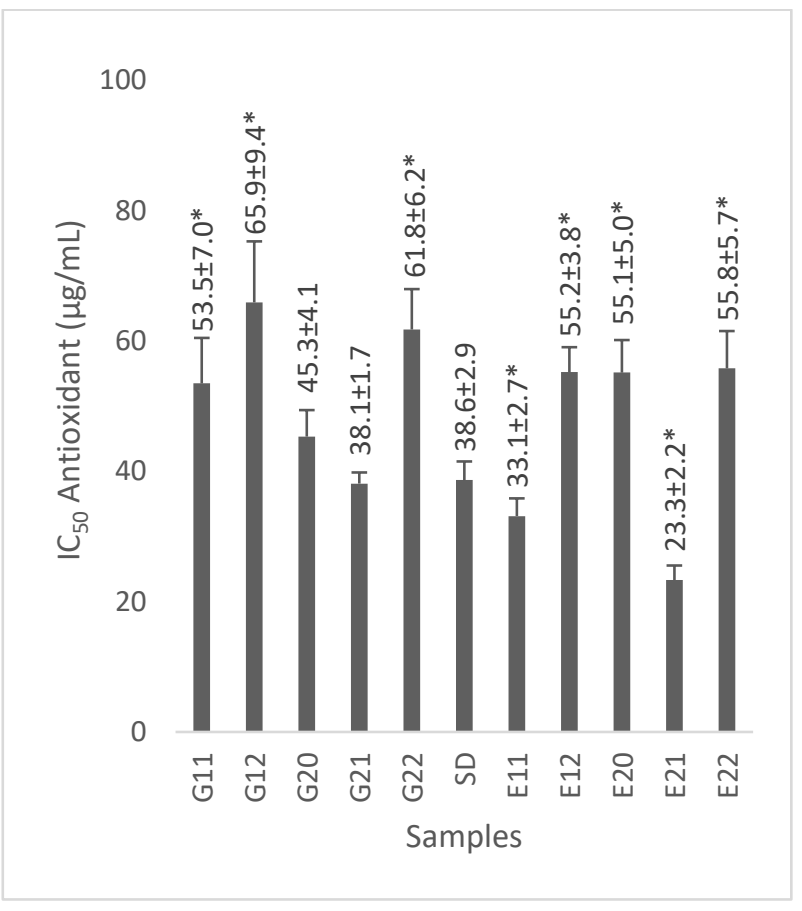

Figure 6. $\mathrm{IC}_{50}$ of antioxidant activity of dried Mekai leaves from sun drying, gas, and electric ovens at various drying temperatures and durations.

Values are presented in average \pm standard deviation. Asterisk (*) indicates the respective value significantly different $(p<0.05)$ in comparison to the sun-dried value.

\subsection{Amino Acid Content}

Drying strategies determine protein stability in the dried products; therefore, it is crucial to find the most suitable conditions for each raw material [47]. For example, hot air drying or convectional mechanical drying is preferable for maintaining amino acids for coffee bean products [48]. Furthermore, each product has a unique profile of amino acids that become markers in the drying process. For example, arginine, glutamate, aspartic acids, and leucine are markers for Mekai leaves. After drying under the sun, the concentration of arginine, leucine, and isoleucine increased more than three folds.

In contrast, the concentration of glutamate, aspartic acid, and other amino acids increased slightly higher than two folds (Figure 7). The drying may affect individual amino acid concentrations. For example, methionine and cystine are the two limiting amino acids during the drying 
of Naga king chili [49]. Leucine, lysine, and isoleucine are amino acid markers in tomato drying [50].

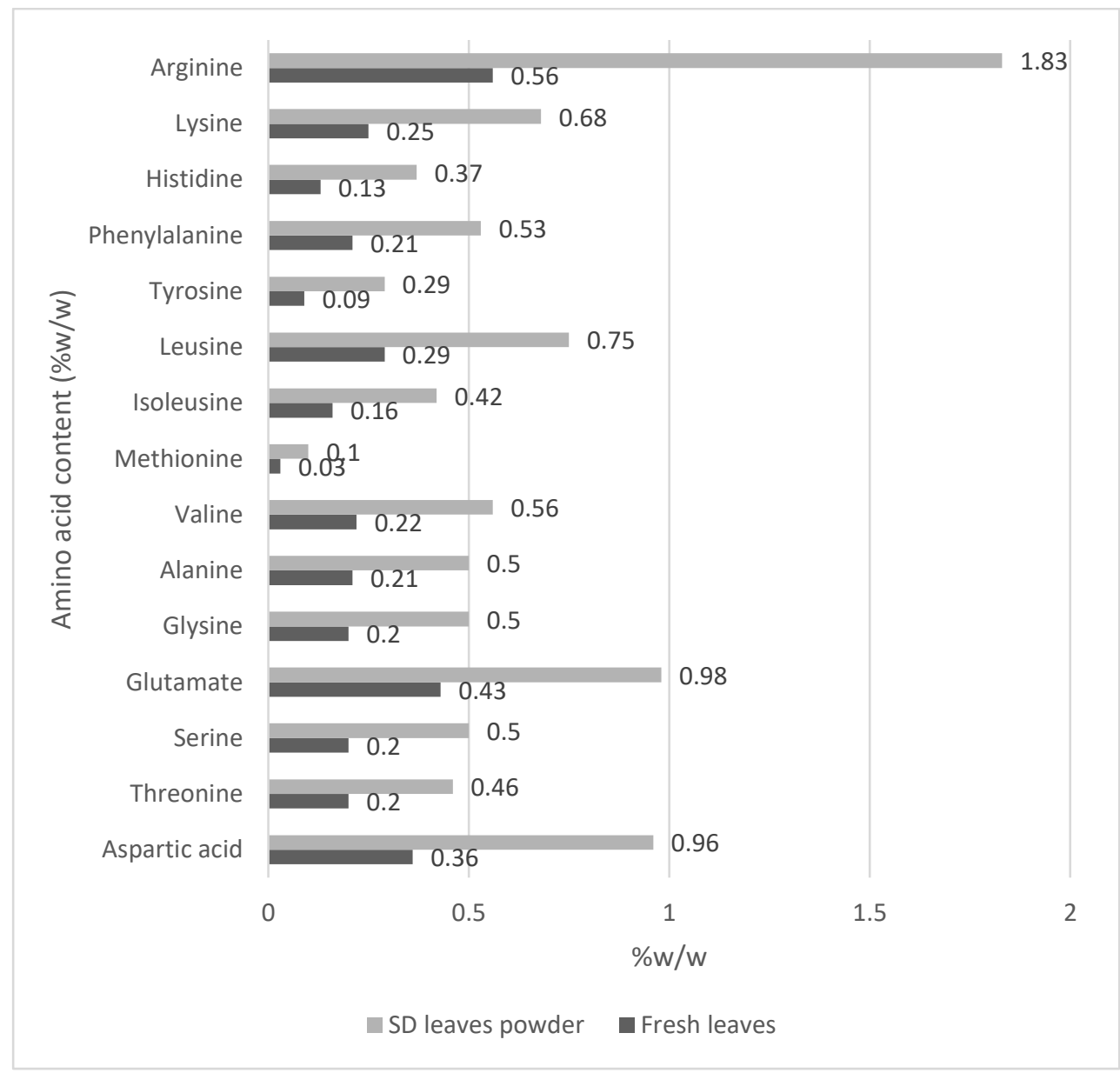

Figure 7. Amino acids profile of fresh and sundried Mekai leaves.

\section{CONCLUSION}

Moisture contents of dried Mekai leaves ranged from $6.95 \pm 0.09$ to $9.30 \pm 0.60 \%$ (w/w). Dried Mekai leaves had ash and protein contents of $4.22-5.47 \%$ and $15.7-20.6 \%$ $(\mathrm{w} / \mathrm{w})$, respectively. The best condition for moisture and ash contents were obtained from electric oven drying at $60{ }^{\circ} \mathrm{C}$ for 3.5 hours. Various drying methods had no significant effect on protein content, excepted for electric oven drying at $60{ }^{\circ} \mathrm{C}$ for 3.5 hours, giving $16.9 \pm 0.0 \%$ $(\mathrm{w} / \mathrm{w})$. Sundried Mekai has the most negligible value of TPC, while samples dried with an electric oven generally have better TPC than samples dried with a gas oven. Both electric and gas oven drying at $60{ }^{\circ} \mathrm{C}$ for 2.5 hours produced higher flavonoids and antioxidant activities than other drying conditions in the same group. Arginine, glutamate, aspartic acids, and leucine are markers for Mekai leaves. After sun drying, the arginine, leucine, and isoleucine concentrations in Mekai leaves increased higher than concentrations of other amino acids.

\section{AUTHORS' CONTRIBUTIONS}

Kristopal and Yuda Hendriansyah collected data. The conceptualization, methodology, software, validation, formal analysis, investigation, data curation, writing, review, and editing were done by Miftakhur Rohmah, Nur Amaliah, and Anton Rahmadi, supervision by Miftakhur Rohmah, and project administration by Bernatal Saragih. All authors have read and agreed to the published version of the manuscript.

\section{ACKNOWLEDGMENTS}

The authors thanked the Faculty of Agriculture, Mulawarman University.

\section{REFERENCES}

[1] S. Sudrajat, R. Kartika, S. Sudiastuti, "Metabolites fingerprint leaf extract of Bekkai plant, Albertisia papuana Becc as natural food seasonings using by 
Dayak Ethnics Community In North Kalimantan, Indonesia”, Journal of Physics: Conference Series. 1277(1) (2019) 1-5 DOI: doi:10.1088/1742$6596 / 1277 / 1 / 012020$

[2] N. Saupi, A.A. Saidin, M.H. Zakaria, S.R. Sarbini, N.A. Yusli, "Ethnobotanical study of indigenous leafy vegetables among local communities in Bintulu, Sarawak, Malaysia, Borneo", Journal of Resource Science and Technology 10(2) (2020) 155-165

[3] R, Maharai, A. Fernandes, M. Turjaman, H. Kuapradini, G, Lukmandaru, "Chemical and organoleptic properties of bekai (Pycnarrhena tumefacta Miers) leaves for flavouring agent (biovetsin)", Indonesian Journal of Forestry Research 7(2) (2020) 121-133 DOI: $\underline{10.20886 / \mathrm{ijfr} .2020 .7 .2 .121-133}$

[4] BS. Swasta, "Potential Species as a Food Source in Wehea Forest, East Kalimantan, Joint Symposium on Tropical Studies (JSTS-19). Atlantis Press. 2021

[5] A. Alim, H. Song, T Zou, “Analysis of meaty aroma and umami taste in thermally treated yeast extract by means of sensory-guided screening" European Food Research and Technology 246(10) (2020) 2119-2133 DOI: https://doi.org/10.1007/s00217020-03561-5

[6] F.B. Siewe, T.G. Kudre, B. Narayan, "Optimisation of ultrasound-assisted enzymatic extraction conditions of umami compounds from fish byproducts using the combination of fractional factorial design and central composite design" Food Chemistry 334 (2021) 127498.

[7] Y. Dang, L. Hao, J. Cao, Y. Sun, X. Zeng, Z. Wu, D. Pan, "Molecular docking and simulation of the synergistic effect between umami peptides, monosodium glutamate and taste receptor T1R1/T1R3" Food chemistry 271 (2019) 697-706.

[8] M. Melis, I.T Barbarossa, "Taste perception of sweet, sour, salty, bitter, and umami and changes due to 1arginine supplementation, as a function of genetic ability to taste 6-n-propylthiouracil", Nutrients 9(6) (2017) 541

[9] A. Karen, A. Sharp, "Food first strategies incorporating a commercial wound supplement to support intake and overcome taste fatigue", Wound Practice \& Research 29(2) (2021)

[10] J. Barimah, P. Yanney, D. Laryea, C. Quarcoo, "Effect of drying methods on phytochemicals, antioxidant activity and total phenolic content of dandelion leaves", American Journal of Food and Nutrition 5(4) (2017) 136-141.
[11] A.S. Rosaln, A. Ismail, Y. Ando, A. Azlan, "Effect of drying methods and parameters on the antioxidant properties of tea (Camellia sinensis) leaves, Food Production", Processing and Nutrition 2(1) (2020) $1-11$.

[12] AOAC. Official Methods of Analysis of Association of Official Analytical Chemist, 2020, AOAC International, Virginia USA

[13] A. Mu'nisa, T. Wresdiyati, N. Kusumorini, dan W. Manalu, "Aktivitas Antioksidan Ekstrak Daun Cengkeh, Jurnal Veteriner”, 13(3) (2012) 272-277.

[14] Nurhayati, K. Siadi, Harjono, "Pengaruh Konsentrasi Natrium Benzoat dan Lama Penyimpanan pada Kadar Fenolat Total Pasta Tomat" Indonesian Journal of Chemistry Science, 1(2) (2012) 158-163.

[15] Y. Zou, Y Lu, D. Wei, “Antioxidant Activity of Flavonoid Rich Extract of Hypericum pertoratum L. in Vitro" Journal Agriculture and Food Chemistry, 52(16) (2004) 5032-5039.

[16] H Farhan, H Rammal, A. Hijazi, H Hamad, A Daher, M. Reda, B Badran. "Invitro Antioxidant Activity of Ethanolic and Aqueous Extracts from Crude Malva parviflora L. Grown in Lebanon". Asian Journal of Pharmaceutical and Clinical Research, 5(3) (2012) 234-238.

[17] Unit Laboratorium Jasa Pengujian, Kalibrasi dan Sertifikasi Institut Pertanian Bogor procedure number IK.LP-04.7-LT-1.0

[18] L.M. Garcìa, C. Ceccanti , C. Negro, L.D. Bellis, L. Incrocci, Alberto Pardossi, et al., "Effect of drying methods on phenolic compounds and antioxidant activity of Urtica dioica L. Leaves", Horticulturae, 7 (1) (2021) 10.

[19] J. Barimah, P. Vanney, D Laryea, C. Quarcoo, "Effect of drying methods on phytochemicals, antioxidant activity and total phenolic content of dandelion leaves" American Journal of Food and Nutrition 5(4) (2017) 136-141 DOI: 10.12691/ajfn5-4-4

[20] A. Lingayat, V.P. Chandramohan, V.R.K. Raju, "Design, development and performance of indirect type solar dryer for banana drying", Energy Procedia $109 \quad$ (2017) 409-416 https://doi.org/10.1016/j.egypro. 2017.03.041

[21] B. Tiencheu, A.C. Egbe, A.U. Achidi, A.F.T.Ngongang, N.Tenyang, F.T. Djikeng et al., "Effect of oven and sun drying on the chemical properties, lipid profile of soursop (Annona muricata) seed oil, and the functional properties of 
the defatted flour", Food Science \& Nutrition 9(8) (2021) 4156-4168

[22] A.M. Mafokoane, M. S. Mphosi, K. G. Shadung, "Effect of time-based oven-drying on the microbial profiling of cowpea [Vigna unguiculata (L.) Walp.] leaves", Research on Crops 20(3) (2019) 625-628.

[23] S. Kamiloglu, G. Toydemir, D. Boyacioglu, J. Beekwilder, R.D. Hall, E. Capanoglu, “A review on the effect of drying on antioxidant potential of fruits and vegetables", Critical reviews in food science and nutrition 56.sup1(2016) S110-S129.

[24] S. Lenaerts, M. Van Der Borght, A. Callens, L Van Campenhout, "Suitability of microwave drying for mealworms (Tenebrio molitor) as alternative to freeze drying: Impact on nutritional quality and colour”, Food chemistry 254 (2018) 129-136.

[25] K. D. Tolera, S. Abera, "Nutritional quality of Oyster Mushroom (Pleurotus Ostreatus) as affected by osmotic pretreatments and drying methods", Food science \& nutrition 5(5) (2017) 989-996.

[26] OA Ajayi, O.O. Ola, O.O. Akinwunmi, "Effect of drying method on nutritional composition, sensory and antimicrobial properties of Ginger (Zinginber officinale)", International Food Research Journal 24(2) (2017)

[27] A. Maray, M.K. Mostafa, AEMA El-Fakhrany, "Effect of pretreatments and drying methods on physico-chemical, sensory characteristics and nutritional value of oyster mushroom", Journal of Food Processing and Preservation 42(1) (2018) e13352.

[28] VK Maurya, K.M. Gothandam, V. Ranjan, A Shaky, S. Pareek, "Effect of drying methods (microwave vacuum, freeze, hot air and sun drying) on physical, chemical and nutritional attributes of five pepper (Capsicum annuum var. annuum) cultivars", Journal of the Science of Food and Agriculture 98(9) (2018) 3492-3500.

[29] Radha, M. Kumar, S. Puri, A. Pundir, S.P. Bangar, S. Changan, et al., "Evaluation of Nutritional, Phytochemical, and Mineral Composition of Selected Medicinal Plants for Therapeutic Uses from Cold Desert of Western Himalaya", Plants 10(7) (2021) 1429.

[30] Y. Ayalew, N. Retta, G. Desse, A. Mohammed, A. Mellesse, "Amino acid profile and protein quality in tuber and leaf of Coccnia abyssinica (Lam.)(Cogn.) accessions of Ethiopia", Food science \& nutrition 5(3) (2017) 722-729.

[31] E.S. Krul, "Calculation of nitrogen-to-protein conversion factors: A review with a focus on soy protein", Journal of the American Oil Chemists' Society 96(4) (2019) 339-364.

[32] Q. Zhang, D. Qi, X. Dong, X. Li, L.Cheng, H. Liu, et al., "Amino acid composition, protein content and accurate nitrogen-to-protein conversion factor for sheepgrass (Leymus chinensis)", Botany 98(3) (2020) 137-146

[33] H. Yeoh, Wee, Y. "Leaf protein contents and nitrogen-to-protein conversion factors for 90 plant species", Food Chemistry, 49(3) (1994) 245-250.

[34] G. Reineccius, "Use of proteins for the delivery of flavours and other bioactive compounds", 2019, Food hydrocolloids 86 (2019) 62-69.

[35] Ş. Bilgin, H.Ö. Tanrikulu, “The changes in chemical composition of Holothuria tubulosa (Gmelin, 1788) with ambient-drying and oven-drying methods", Food science \& nutrition 6(6) (2018) 1456-1461.

[36] K. Sukadeetad, W. Nakbanpote, M. Heinirich, N. Nuengchamnong, "Effect of drying methods and solvent extraction on the phenolic compounds of Gynura pseudochina (L.) DC. leaf extracts and their anti-psoriatic property", Industrial Crops and Products, $120 \quad$ (2018) 34-46 DOI: https://doi.org/10.1016/j .indcrop.2018.04.020

[37] S. Şahin, E. Elhussein, M. Bilgin, J.M. Lorenzo, F.J. Barba, S. Roohinejad, "Effect of drying method on oleuropein, total phenolic content, flavonoid content, and antioxidant activity of olive (Olea europaea) leaf", Journal of Food Processing and Preservation 42(5) (2018) e13604.

[38] R.O. Lamidi, L. Jiang, P.B. Pathare, Y.D. Wang, A.P. Roskilly, "Recent advances in sustainable drying of agricultural produce: A review", Applied energy 233 (2019) 367-385.

[39] A.O. Ademiluyi, O.H. Aladeselu, G. Oboh, A.A. Boligon, "Drying alters the phenolic constituents, antioxidant properties, $\alpha$-amylase, and $\alpha$ glucosidase inhibitory properties of Moringa (Moringa oleifera) leaf", Food science \& nutrition 6(8) (2018) 2123-2133.

[40] I. Maseko, T. Mabhaudhi, B. Ncube, S. Tesfay, H.T. Araya, M.K. Fessehazion, et al., "Postharvest drying maintains phenolic, flavonoid and gallotannin content of some cultivated African leafy vegetables", Scientia Horticulturae 255 (2019) 7076.

[41] M.S. Alkaltham, A. Salamatullah, K. Hayat, "Determination of coffee fruit antioxidants cultivated in Saudi Arabia under different drying conditions", Journal of Food Measurement and Characterization, 14(3) (2020) 1306-1313. 
[42] F. Martinez-Morales, A.J. Alonso-Castro, J.R. Zapata-Morales, C. Carranza-Alvarez, O.H. Aragon-Martinez, "Use of standardized units for a correct interpretation of IC50 values obtained from the inhibition of the DPPH radical by natural antioxidants", Chemical Papers 74(10) (2020) 3325-3334.

[43] BB de Menezes, L.M. Frescura, R. Duarte, M.A. Villetti, M.B. da Rosa, "A critical examination of the DPPH method: Mistakes and inconsistencies in stoichiometry and IC50 determination by UV-Vis spectroscopy", Analytica Chimica Acta 1157 (2021) 338398.

[44] V. Alfeo, D. Planeta, S."Cherry Tomato Drying: Sun Versus Convective Oven." Horticulturae 7.3 (2021) 40.

[45] H, Çoklar, M. Akbulut, "Effect of sun, oven and freeze-drying on anthocyanins, phenolic compounds and antioxidant activity of black grape (Ekşikara)(Vitis vinifera L.)", 2017, South African Journal of Enology and Viticulture 38(2) (2017) 264-272.

[46] MRD. Mashkani, K. Larijani, A. Mehrafarin, H.N. Badi, "Changes in the essential oil content and composition of Thymus daenensis Celak. under different drying methods", Industrial Crops and Products 112 (2018) 389-395.

[47] F. Emami, A. Vatanara, E.J. Park, D.H. Na, "Drying technologies for the stability and bioavailability of biopharmaceuticals" 2018, Pharmaceutics 10(3) (2018) 131.

[48] W. Dong, R.Hu, Z.Chu, J.Zhao, L.Tan, "Effect of different drying techniques on bioactive components, fatty acid composition, and volatile profile of robusta coffee beans", Food Chemistry 234 (2017) 121-130.

[49] R. Ananthan, K. Subhash, T. Longvah, "Capsaicinoids, amino acid and fatty acid profiles in different fruit components of the world hottest Naga king chilli (Capsicum chinense Jacq)", Food chemistry 238 (2018) 51-57.

[50] V. Nour, T.D. Panaite, M. Ropota, R.Turcu, I.Trandafir, A.R.Corbu, "Nutritional and bioactive compounds in dried tomato processing waste", CyTA-Journal of Food 16(1) (2018) 222-229. 